\section{Making a Place for Makerspaces in Information Literacy}

\begin{abstract}
Leah Mann
Leah Mann is Library Media Services Instructional Specialist at Lewisville Independent School District, Lewsville, Texas.
\end{abstract}

Correspondence concerning this column should be addressed to Sarah LeMire; e-mail: slemire@tamu.edu.
In recent years, many libraries have experimented with the idea of creating makerspaces in their facilities. Library makerspaces provide patrons with opportunities to experiment not only with different technologies, but with different ways of thinking. In this column, Leah Mann explores the relationship between making and information literacy and describes how librarians can use makerspaces to create unique pedagogical opportunities to develop practical real-world skills, build problem-solving abilities, and enhance knowledge transfer. She explains how the maker movement can affect not only school libraries, but other types of libraries as well._-Editor

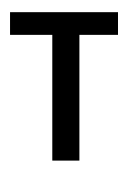

he maker movement has been gaining momentum in recent years, and librarians of all types have looked for ways to include makerspaces and maker activities into their programming while still addressing the more traditional aspects of the field. This article attempts to evaluate makerspaces and their place in libraries through the information literacy lens. While the bulk of the examples in this article are representative of school libraries, public and academic libraries can adapt these recommendations to fit their needs or use them as suggestions of how to support and partner with their school counterparts.

The American Library Association's (ALA) Libraries Transform campaign identifies a need for society to not only make things to tap into its creativity, but to learn to formulate its own questions and find ways to answer them. ${ }^{1}$ While the idea of adding 3D printers, laser cutters, and sewing machines to the list of materials library users can check out and use might seem odd, it makes sense when considered through the lens of information literacy. For those who work in school libraries, the Future Ready Librarians framework, which is an extension of the Future Ready Schools initiative launched under President Obama in 2014, supports this by placing personalized student learning at the heart of a successful school library program. Makerspaces are a prime opportunity for libraries to address the personal needs of not only students, but all library users in all library environments.

Since 2006, and the inaugural Maker Faire in San Mateo, California, the maker movement has gained a large following among the library community. By 2014, there were roughly 135 million adults in the United States who identified as makers. ${ }^{2}$ These individuals are do-it-yourselfers who look for ways to creatively build and design their own materials and resources, some for entrepreneurial purposes. Through access to 3D printers, laser cutters, and sewing machines, as well as other materials, technological and nontechnological Americans are coming together in their desire to make. ${ }^{3}$ The idea 
of including makerspaces in libraries dates back to 2011 and is attributed to Fayetteville Free Library in New York, where library users were allowed to use the library's 3D printer. ${ }^{4}$

The US Department of Labor states 65 percent of today's school-age children will grow up to work in careers that do not currently exist. ${ }^{5}$ It is no longer enough to only focus on the information-retrieval side of information literacy. Instead, librarians should broaden the definition to include the power of the maker movement to help library users locate, evaluate, and effectively use resources and materials to explore the world around them, tap into hidden passions and skills to which they can apply their learning. Making is an additional facet of information literacy, and it belongs in libraries. Whether through physical makerspaces, maker clubs, mobile maker labs on busses and vans, or maker kits circulated along with books, many school, public, and academic librarians have embraced the maker movement as another way to meet the needs of the communities they serve and prepare citizens for these future jobs. Additionally, many of the nation's state and national library associations, as evidenced by the programs and presentations offered at their conferences, are busily promoting the maker movement. For the past three years the Texas Library Association has highlighted makers in its Innovation Lab at their annual conference in April. This area is always popular with attendees, and the high attendance at the presentations in the lab is a strong example of the interest librarians hold in the maker movement.

\section{MAKING AND INFORMATION LITERACY}

According to ALA, information literacy is "a set of abilities requiring individuals to recognize when information is needed and have the ability to locate, evaluate, and use effectively the needed information." ${ }^{16}$ Traditionally, this definition has guided librarians in how they assist their library users with locating information through research and retrieval, and one of information professionals' main responsibilities is to teach others how to access resources autonomously.

\section{Examples from the Field}

Many public, academic, and school librarians bring makerspaces, information literacy, and subject-matter content together in unique ways. An example from school libraries, from a district in North Texas, is partnership between one of the district's librarians, fifth-grade science teachers, and the district's science department to review concepts that data had showed students were weak in. With this data and the science content in hand, the collaborative team planned maker stations that allowed students to construct meaning using traditional maker materials such as Makey Makeys, LED lights, coin cell batteries, and littleBits. Having a challenge in front of them and the opportunity to carefully evaluate and analyze materials provided to them gave students a real-word opportunity to apply testable material. Watching the learning take place was a feast for the eyes. Students were actively engaged, excited to learn, and expressed a better understanding of the concept they were reviewing.

Another example of how this same school district answers the call for deeper maker experiences is through their library department's Mobile Transformation Lab. This specialist-driven initiative coaches campus librarians and their collected team of teachers and content specialists in ways to embed maker learning in their lessons. One example of the lab at work involved seventh-grade math students who were challenged to solve a recycling problem on their campus. Using IDEO's Design Thinking framework, ${ }^{7}$ students had to research feasible recycling receptacles they could design and 3D print to pitch ideas for possible implementation. The iterative process of brainstorming, prototyping, and testing, all while learning the math skills highlighted in the curriculum, gave students a real-world example of how math is used in design.

By approaching making in a way that is embedded in instruction with the guidance of coaches, the classroom teacher gained confidence in using a 3D printer as well as how to teach using it, and students had to apply information literacy skills to create their proposed product and solution. The supporting role played by the library department's specialists in implementing the technology and the processes made the teacher feel comfortable in trying something new. It was a great opportunity for the students to see math applied in true-to-life ways.

Information literacy, the real world, and makerspaces can be seen coming together at public libraries that host events where library patrons of all ages use app-making software to create apps to solve real-world problems. Another example is university library labs where students can use a wide variety of machines and equipment to build projects for their coursework. Both examples allow for more engaged library patrons who use the makerspace resources and programming available to them to connect their learning and interests to relevant issues and needs.

\section{NEW LITERACIES}

How do examples of instruction and activities like the ones above, and the maker movement in general, support and expand the idea of information literacy? One way is through technology literacy. The Colorado Department of Education defines technology literacy as "the ability to appropriately select and responsibly use technology." Society for Technology in Education (ISTE) identifies technology literacy as the ability to demonstrate skills in several areas, including the following:

- Creativity and innovation: Students use technology to demonstrate creative thinking, problem solving, and knowledge construction. 


\section{INFORMATION LITERACY AND INSTRUCTION}

- Communication and collaboration: Students use technology to communicate and collaborate in order to enhance their learning or the learning of others.

- Research and information fluency: Students use technology to find and use accurate, up-to-date information.

- Digital citizenship: Students understand what it means to be a citizen in the digital world and practice ethical behavior when they use technology.

- Technology operations and concepts: Students illustrate an understanding of technological systems and concepts. ${ }^{9}$

Using makerspaces to provide users opportunities to learn autonomously and hone their technology literacy skills carries many benefits, namely equalization of opportunities and a closing of the digital divide. ${ }^{10}$ This occurs when library patrons of all backgrounds and experiences gain access to the resources they may not otherwise have. In the school setting, a student's schedule, socio-economic status, or language may keep them from taking the classes that allow them to learn to use traditional maker tools. However, when the library provides maker experiences throughout the day for little or no money, anyone can have a chance. Additionally, these opportunities place library users at the center of their learning and understanding and puts those users in the driver's seat. ${ }^{11}$ This engages them more, which in turn encourages them to want to learn more, possibly leading to a future career or opportunities they may not have ever been able to consider.

Just as makerspaces help close the digital divide, they also provide opportunities for individuals to hone skillsets not typically available in the traditional classroom or academic setting. ${ }^{12}$ Not every student has an opportunity to take Career Technical Education or vocational courses, whether due to their schedule or availability at their campus. Some people are more interested in training for a vocation, versus going to a four-year university, ${ }^{13}$ and makerspaces can provide a launching point for them to discover what their future career could be.

Another way makerspaces support literacy is through tool literacy. Similar to teaching people how to identify when to use a database versus a search engine, makerspaces can be used to teach users how to decide when a physical tool is needed and which tool is best for the job at hand. This skill can be especially beneficial for students, as it prepares them to be independent adults with the life skills they will need, such as knowing which screwdriver to use and when. ${ }^{14}$ Joyce Valenza likens tool literacy to the difference between a cook who follows a recipe and a chef who can create unique recipes using the ingredients they have in new and exciting ways. ${ }^{15}$ Tool literacy boils down not just to real-life skills everyone needs at all stages of life, but focusing on the process at hand. Evaluating how a tool can be used in various ways teaches individuals how to engage in workflow and think critically about how they want to achieve their goal, which is higher-level thinking at its finest.
In the school setting, as students learn to use the tools and the technology, reading is involved. The ability to read instructional texts and infographics, which are often how instruction manuals are delivered these days, is just as much a part of information literacy as more traditional print. Anyone who has ever had to use the instructions to build furniture from IKEA can relate to this! When students have opportunities to read these kinds of texts in the context of making, they reinforce all literacy skills simultaneously.

\section{MAKER LITERACY AND THE REAL WORLD}

A white paper published by Discovery Education touts the need for students to learn to read and think like a real-world expert. ${ }^{16}$ In it, Karen Beerer calls for more robust digital and media resources that bring everyday life into instruction and experiences through a variety of perspectives. Libraries can leverage hands-on maker activities to broaden the experiences and perspectives of the community they serve while exposing users to industry-specific vocabulary and knowledge. Through makerspace instruction, students as young as the primary grades express their learning through specialized vocabulary. First graders are fully capable of identifying when code they are using via code.org needs to be "debugged," and second graders have no problem explaining the "algorithm" they have created to express how they built a structure. While they are not explicitly learning a computer language, they are learning the tenets of computational thinking. What makes these statements from students so powerful is when the making is embedded in the instruction and where they can see the connection between what state standards require they know and what industry will want them to be able to do.

Students expressing their learning through real-world representations is nothing new. As professionals who have studied how to work with children of all ages and stages, teacher librarians are well versed in constructivist learning theories. If teacher librarians are truly preparing students to be future ready in accordance with the Future Ready Librarians Framework and are providing opportunities for them to compete in tomorrow's job market, then it is important to find ways for them to practice these skills in real-world settings where they have an opportunity to learn from failure. This preparation can be empowered when school, public, and academic libraries partner together to provide students robust access to a variety of resources, filling in where the other institutions leave off.

\section{FAILURE AND INFORMATION LITERACY}

Thanks in part to standardized testing, failure became a scary word that carries deeply negative connotations. Luckily, failure is making a comeback thanks to the maker movement, and it definitely has a place in information literacy. 
What the maker movement, failure, and information literacy all have in common is an opportunity for library users to learn for themselves and choose how they want to learn from a mistake going forward. They can choose what they believe is the best tool for the job at hand, and if their project or design does not quite turn out as envisioned, they have the independence to decide what they will change next time. An example would be if a library patron's design using the Tinkercad 3D design tool did not print out the way they wanted on the 3D printer, they could use this knowledge to learn new skills for better print quality next time. As individuals experience these kinds of failures, they become more comfortable with things not always working the first time or how they envisioned. In simplified terms, if information literacy is about locating the right information using the right tool at the right time, there will be times people do not choose appropriately. The same can be said for making.

Another interesting point about failure is it provides an opportunity to seek out answers and practice giving and receiving feedback. The act of looking up instructions on how to troubleshoot a robot or how to correct a missed stitch in a knitted scarf provides individuals great opportunities to practice information retrieval that is relevant and more meaningful to them. In any library setting, these instances also allow users the means to seek out others whose experiences make them "experts," which is a great life skill.

\section{TRANSFERRING KNOWLEDGE IS TRUE LEARNING, AND A NECESSARY SKILL}

According to Scott Walter, "The abilities to strategize, search, evaluate, and engage information resources represent transferable skills relevant both to the workplace and to one's role as an engaged and informed member of our society."17 This manifestation of information literacy is exactly what makerspaces are about. Makerspaces give library users the freedom to apply what they have learned in new ways. Designing a Makey Makey-powered cardboard instrument lets users explore their knowledge of circuits. Coding and computational thinking allow school-age members of the community to apply the story elements of sequence of events and cause and effect. Occasions to use knowledge in the real world are especially powerful when librarians collaborate to help solidify the relationship between making and information literacy.

\section{YOU AREN'T ABANDONING THE PROFESSION!}

It can seem as though librarians are abandoning their library and literacy roots to incorporate more emerging technology and maker resources. Luckily, library professionals don't have to choose one aspect of library instruction over another. Traditional literacy and makerspaces not only can both hold a place in our libraries, they can do so simultaneously.
When libraries include makerspaces, they have not only provided physical resources to their users but also have facilitated an opportunity for them to physically explore a topic of interest through provided resources rather than simply reading about it. What is especially exciting is when print materials and maker activities converge. There are many ways to approach makerspaces. It can be a complete learning area, a dedicated shelf of resources, a cart of supplies, and can be covered through various means of scheduling. All these ways are correct and have a place. It is best to start slow. Just because the space is built does not mean the users will come! It is a new journey for them, too, and it will take some time for them to learn how to fully harness what is available. It is important to have a vision of how the space to operate. For some, makerspaces provide a great club activity. Others choose to employ makerspaces as a oncea-week activity or reserved for specific grades or groups. Some makerspaces use more craft supplies, while others are technology heavy. Consider patrons' needs and use those to drive decisions about what is purchased and how the makerspace is scheduled.

As mentioned earlier, standardized testing has done a lot to create a lens through which activities and programs are evaluated in the school setting. Arguably the most powerful way to implement maker education at the school level, in a way that speaks to teachers and administrators, is through standards-based and curriculum-embedded maker education. This provides a rich opportunity for students to use their information literacy skills in a real-world, constructivist way while still mastering content required by state and national standards. Even without a physical space, or abundant maker supplies, information literacy can still be reinforced through maker education. Design thinking is a great way to facilitate opportunities for library users to think critically about a problem, and a paper and pencil are the minimum materials needed to engage in the process and think in new ways.

\section{FINAL THOUGHTS}

It can seem overwhelming and costly to take the plunge into makerspace programming. However, makerspaces can elevate library programming to new heights and can be a great way for library users to authentically learn and utilize information literacy skills. Luckily, the best way to start a makerspace is to do just that-start. Begin with an afterschool making club, investigate ways to establish a culture of making using low- or no-tech resources, or weave making into instruction when teaching. No matter how small the start, or how access is provided, just jump in. The information literacy skills of your users will be greatly strengthened. The only thing necessary for a makerspace program to be successful is to be open to learning along the way, and keep what is best for the community at the heart of your maker journey. 


\section{INFORMATION LITERACY AND INSTRUCTION}

\section{References}

1. "Libraries Transform," American Library Association, accessed October 18, 2018, http://www.ilovelibraries.org/librariestrans form/.

2. Tim Bajarin, "Why the Maker Movement is Important to America's Future," Time, May 19, 2014, http://time.com/104210 /maker-faire-maker-movement/.

3. Bajarin, "Why the Maker Movement."

4. Deborah Fallows, "How Libraries are Becoming Modern Makerspaces," Atlantic, March, 11 2016, https://www.theatlantic.com /technology/archive/2016/03/everyone-is-a-maker/473286/.

5. Azadeh Jamalian, "The Role of School Libraries in the 21st Century Maker Movement," white paper, littleBits, June 6, 2018, http://e.littlebits.com/librariansmakerspaces.

6. "Information Literacy Defined," American Library Association, accessed October 17, 2018, http://www.ala.org/Template .cfm?Section=Home\&template $=/$ ContentManagement/Content Display.cfm\&ContentID=33553\#ildef.

7. "Methods," IDEO Design Kit, http://www.designkit.org/methods.

8. Caitrin Blake, "Defining Technology Literacy: Skills Students Need for Personal and Professional Success," CBS Connects, accessed August 17, 2018, https://cbsconnects.org/21st-century -skills/.

9. "ISTE Standards for Students," International Society for Technology in Education, accessed August 17, 2018, https://www iste.org/standards/for-students.
10. Laura Fleming and Billy Krakower, "Makerspaces and Equal Access to Learning," Edutopia (blog), July 19, 2016, https://www .edutopia.org/blog/makerspaces-equal-access-to-learning -laura-fleming-billy-krakower.

11. Jamalian, "Role of School Libraries."

12. Diana Rendina, "3 Reasons Why Making and Literacy Aren't Mutually Exclusive," Renovated Learning (blog), January 20, 2017, http://renovatedlearning.com/2017/01/30/making-literacy -arent-mutually-exclusive/.

13. Mark Phillips, "Why We Need Vocational Education," Washington Post, June 5, 2012, https://www.washingtonpost.com /blogs/answer-sheet/post/why-we-need-vocational-education /2012/06/04/gJQA8jHbEV_blog.html?utm_term=.5979d 97 $552 \mathrm{~b} 8$.

14. Rendina, "3 Reasons."

15. Joyce Valenza, "Tool Literacy as a New Process," School Library Journal, May 14, 2016, http://blogs.slj.com/neverendingsearch /2016/05/14/tool-literacy/.

16. Karen Beerer, "Disciplinary Literacy: Teaching Students How to Read Like Scientists," Discovery Education (blog), September 29, 2016, http://blog.discoveryeducation.com/blog/2016/09/29/dis ciplinary-literacy-teaching-students-how-to-read-like-scientists/.

17. Scott Walter, "Information Literacy as a Transferable Skill," Library News for Faculty, January 17, 2017, https://news.library .depaul.press/faculty/2017/01/17/information-literacy-as-a -transferable-skill/. 